\title{
Environmental Monitoring School Based Raspberry
}

\author{
H.Muddassir ${ }^{1)}$, Yunus Tjandi ${ }^{2)}$ \\ ${ }^{2)}$ Education Of Electric Engineering, Technical Of Engineering University State Of Makassar \\ ${ }^{1)}$ Electric Engineering, Technical Of Engineering University State Of Makassar
}

\begin{abstract}
Technology of School Environmental Safety Systems that currently using this day is not all right, especially at schools that are in remote areas. By looking at the current technological advances, the researchers created a device-based on monitoring using Webcam Raspberry whose function is to monitor the entire environment of the school. The results showed that the Software and Monitoring Tool created a good job and be able to monitor and secure the electrical devices that are in the school, both from a distance, or near, by using a Smartphone.
\end{abstract}

Keywords: device monitoring, school environment, raspberry, smartphone.

\section{Introduction}

The development of science very rapidly enable practitioners to always continue to the new ideas that are useful for helping people work and cope with the problems that are often faced by society, including the School.

Generally, social life in the urban / rural in Indonesia for security aspects / supervision is still manual by using the traditional system in the form of siskamling (Security System Environment) or patrolled by village officials or apparatus guard School while using a gong, if it happens from the emergency in the region, such as the event of theft or natural disasters.

Though used, the system / method has some drawbacks, such as:

1) There is nothing evaluation materials to be studied further in case of theft, robbery, fire or disaster,

2) The power of reach kentongan only includes people at the site near the incident,

3) The lack of official records of events that occur in the community.

By looking at the technological developments that occur at this time, it is possible to develop systems / old ways to be more efficient by providing technology enhancements in several sectors, such as: 1) .Make an Environmental Monitoring Tool Based School raspberry in strategic areas to monitor the state of the region as a whole, particularly the region of the school environment, 2). Recording of emergency events that occurred in the community more regularly and in the future can be used as an evaluation for the government or in society, and more specifically for the Principal and all Staff, 3) .In this system images will be displayed in real time. At this time when we are traveling and being outdoors we never know what's going on at home. It's requires technology that can monitor in real time by using the tool produced by the researchers involve using raspberrybased Smartphone to monitor the whole area of the schools.

\subsection{Research purposes}

The general objective of this research is to develop appropriate technology by creating a monitoring tool based raspberry that can help the School to regulate and monitor the school environment in order to avoid the danger of theft is much bother Schools, especially schools that are in remote areas. while the specific objectives of this study are:

1. Produce prototype software raspberry-based monitoring system to help to monitor the whole school environment by using a Smartphone.

2. Generate Prototype raspberry-based monitoring tool that serves to monitor the entire school environment by using a Smartphone.

3. Build the application interface and raspberry-based monitoring system, using smartphones to monitor the entire school environment by using a Smartphone.

\subsection{Urgency Research}

There are some things that are very urgency in this study. Urgency first to be the cornerstone of the necessity of this research is the development of appropriate technologies required by the School (consumers) to secure the environment from the hands of ignorant who have not monitored. Urgency is located on the second aspect of the use and development of existing technologies to further apply to activities that are common in the social life of people in Indonesia, particularly in the Schools located in remote areas. Urgency third is able to

DOI: $10.9790 / 2834-1105018490 \quad$ www.iosrjournals.org $\quad 84 \mid$ Page


monitor the area around the School (monitor) all tools that are in a school environment or school buildings, so that the theft is rampant and perpetrators can be monitored quickly apprehended by the authorities.

\subsection{Assessment Theory}

\section{Studies And Research Relevant References}

The design is a preparatory stage for the design implementation of a web, which describes how a web is formed which can be a drawing, planning and making sketches or arrangement of several separate elements into a unified whole and functioning including configuring components of software and hardware of a web.

With the needs of increasingly complex network services, we need a method that supports the design of the network architecture and design. Cisco introduced a method of designing a network with PPDIOO models, namely, Prepare, Plan, Design, Implement, Operate, and Optimize.

Life cycle model development methods PPDIOO network with this concept, provide the key steps in the success of network planning, on stage design, implementation and operational costs later. Approach with top-down model design, directing the network infrastructure to adapt any applications required by a network. According CCDA 640-864 Official Cert Guide, Cisco has produced a formula lifecycle of network planning, into six phases: Prepare (preparation), Plan (Plan) Design (Design), Implement (Implementation), Operate (Operation) and Optimize (Optimization).

\subsection{Webcam}

Webcam or USB camera is an electronic device used to capture objects in conjunction with a PC or laptop. Webcam can also be used for visual communication so that fellow users can see each other through the internet

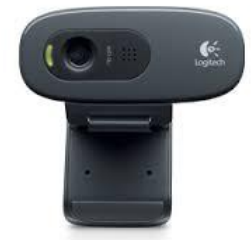

Figure 2.1 webcame logitech C170

\subsection{IP Address [6]}

IP address (Internet Protocol Address or often abbreviated IP) is a row of binary numbers between 32bit to 128-bit addresses used as an identification for each host computer in the Internet. The length of this figure is 32-bit (for IPv4 or IP version 4), and 128-bit (for IPv6 or IP version 6) which indicates the address of the computer on the Internet network based on TCP / IP. Internet Assigned Numbers Authority (IANA), which manages the global IP address allocation. IANA works in Internet Protocol (IP) address is a numeric address assigned to a computer participating in a computer network that uses the Internet Protocol for communication between nodes-nya.Walaupun IP addresses are stored as binary numbers, they are usually shown to facilitate human use of notation, such as 208.77.188.166 (for IPv4), and 2001: db8: 0: 1234: 0: 567: 1: 1 (for IPv6).

Internet Protocol also has the task of routing data packets between networks, the IP address and specifies the location of the source node and the destination node in the topology of the system routhng. To this end, some of the bits in the IP address used to designate a subnetwork. The number of bits is indicated in CIDR notation, which is added to the IP address, for example, 208.77.188.166/24.Sistem IP addressing is divided into two, namely: 1) .IP version 4 (IPv4), and 2) .IP version 6 ( IPv6). Delivery of data in a TCP / IP network based on the IP address of the computer the sender and the recipient's computer. IP address has two parts, the network address (network address) and the address of the local computer (the host address) in the network. The network address used by the router to find a place of a local computer network, moreover local computer address used to identify a computer on the local network.

\subsection{Access Point [9]}

Access point can be found in many places, including homes, businesses and public locations. In most homes, the access point is a wireless router, which is connected to a DSL or modem cable. However, some modems may include wireless capabilities, the modem itself can also be an access point. Large companies often provide some of the access point, which allows employees to connect by wireless (without cables) connected to the central network from various locations.

Access Point serves as Hub / Switch which acts to connect the local network to the wireless network / wireless, at the access point is the data connection / internet transmitted or sent via radio waves, measure the signal strength also affects the area of coverage to be reached, the greater the signal strength (its size in units of $\mathrm{dBm}$ or $\mathrm{mW}$ ) are increasingly reaching. 


\subsection{HTML [1.7,10]}

HTML stands for HyperText Markup Language is a standard programming language used to create a web page, which can be accessed to display a variety of information in an Internet web browser (Browser). HTML link may also be used as a link between the files in the site or in the computer by using localhost, or the connecting link between sites in the internet world. In order to produce a display form that integration formatting simple hypertext written in ASCII format file so that a web page with HTML commands.

HTML is a language that begins before the language widely used in the printing world and publishing called Standard Generalized Markup Language (SGM). This is now an Internet standard HTML controlled and its use is defined by the World Wide Web Consortium (W3C). In 1989, the HTML created by the collaboration with TIM Caillau while working at CERN (CERN is the high energy physics research institute in Geneva)

\subsection{Server}

Server is a computer system that provides a specific kind of service to client in a computer network. The server is equipped with a special operating system to control access and resources in it is usually a particular operating system is called the network operating system or network operating system

\subsection{Raspberry [8,11,12]}

Raspberry $\mathrm{Pi}$ is a credit card-sized computer devices, really practical. The operating system is planted on an SD Flash Card, which makes it very easy to be replaced and exchanged. The potential is incredible, from the already or not yet been explored, but it has been tested as a multimedia player with streaming capabilities, as the game machine, internet browsing and as a mainboard hardware development.

This allows the device to be used as an educational tool for people of all ages and skill levels. The interest in Raspberry Pi device is extraordinary, and has far exceeded expectations. Professional IT, electronics experts and newcomers are all eager to 'put' their hands on this little device and everyone agrees, this device will be large and growing. There are several ways to explain about the things that can be done by the Raspberry Pi including the following:

\subsubsection{General Purpose Computing}

Keep in mind that the Raspberry Pi is a computer and does in fact can be used as a computer. Once the device is ready for use we could choose to boot directly into the GUI (Graphical User Interface) and in which there is a web browser which is a computer application that is widely used today. The device also can be installed many free applications such as Office librery used for office jobs.

\subsubsection{Project Platform}

Raspberry Pi from a computer are generally not in terms of price and size, but also because of its ability to integrate with electronic projects

\subsubsection{Learning to Program}

Raspberry $\mathrm{Pi}$ is basically intended as an educational tool to encourage children to experiment with computers. This device is mounted with interpreters and compilers for various programming languages.

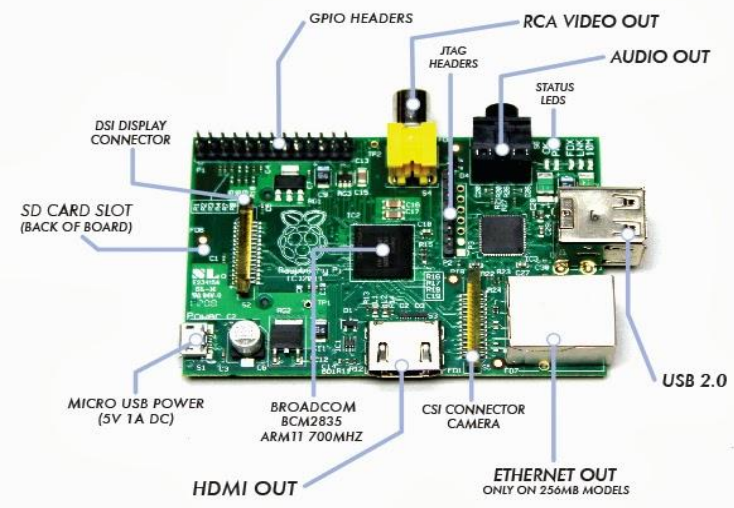

Figure 2.2 Raspberry ${ }^{[8,11,12]}$

\section{Relevant Research}

Christopher D.Celestial.2013 in journals about Smart Home System, which utilizes Web Service Infrastructure The study produced using a microcontroller to establish communication based on Android [1], 
Drajat, Iwan Setiawan. 2011 discusses Application Smart Card that serves as a key Elektronics on Smart Home [2], Eisa Al Eisa, Imam Bakh, 2012 in the journals on the Implementation of Security Systems in the intelligent home that utilizes RSSI using wireless sensors, whose function is to detect any threat, Information reported via SMS and email [3].

\section{Research Methods}

This study used an experimental method due to its compatibility with the objective to be achieved is to produce and test the feasibility of the resulting product, to achieve these goals must go through certain steps that must be followed to produce these products. The study will include an appliance-based monitoring technology using a Smartphone raspberry.

\subsection{Study Design}

The study design was an important thing in a scientific study, the authors arranged as follows:

1) Variabel free, environmental conditions, accident, disaster, or other emergency matters.

2) Variabel not free, that is people in the school environment.

3) Variabel controlled, Webcam equipment, smartphones, wireless media to connect Webcam, PC Server, a software created and used, as well as electric power required by the device is a tool created.

\subsection{Conducting the design and installation of infrastructure in the form:}

1). Installationa Webcam and an Access Point in a position that has been determined.

2) .Design wireless network topology to connect Webcam, and PC Server.

3).Installation an appropriate wireless network topology that has been made.

\subsection{Make software include:}

1) Design application to receive, process and store the data received by the modem / mobile phone GSM / CDMA connected to the PC Server.

2) Design application for administration (regulation and supervision) to the overall system. 3.4 Research Instruments

The tools THAT used in this study are:

1). PC Server.

2). Media Wireless.

3). Modem GSM / CDMA or Smartphone.

4). Some units Wedcam.

5). UTP cable.

6). Switch / Hub.

7). Tool Programming C ++, Java, PHP and Javascript.

8). Debian Linux Operating System 7.

9). Apache Web Server.

10) .MySQL Server.

\subsection{System Architecture}

Generally, the system is divided into two, namely, Internal and External Systems. Where the External System includes outdoor equipment such as cameras Webcam and the public school environment that acts as a user. Webcams take a pictures in the areas that have been determined for the next data is stored in the server raspberry and HDD.

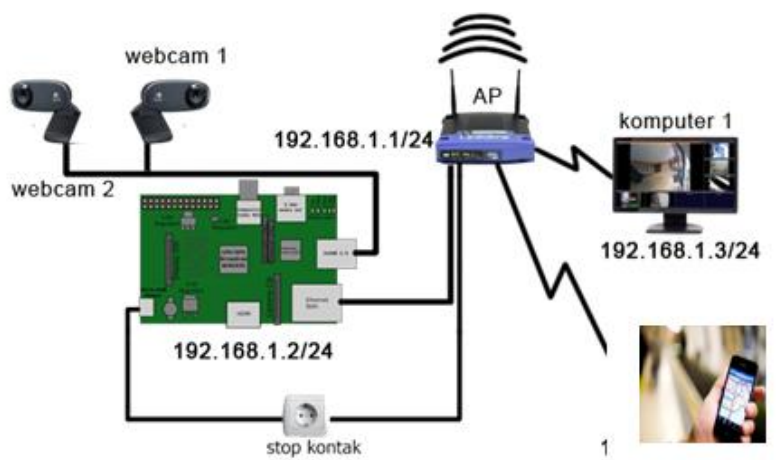

Figure 3.1 Arsitektur Sistem Monitoring 


\subsection{Data Collection Techniques}

Data collection technique used is the technique of interviews with expert control, technical literature, direct measurement techniques and engineering documentation.

\subsection{Test Control System} 1). Using Local Network

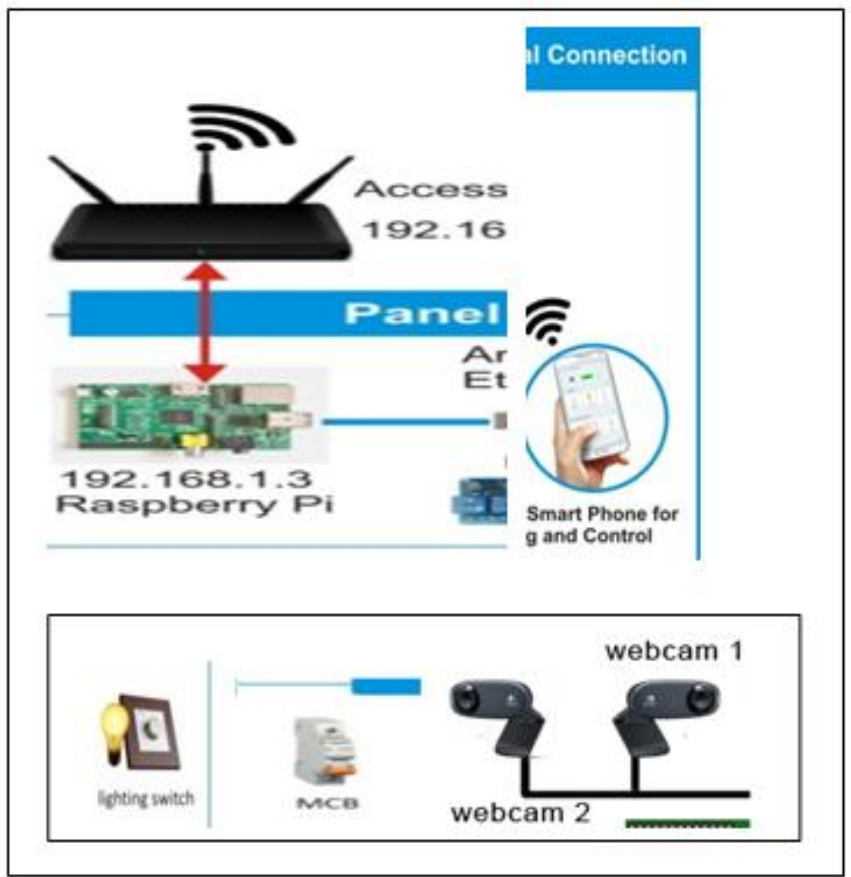

Figure 3.2 Local Network Architecture

In Picture 3.2 above, we see an Access Point that is used as a media liaison between the Smartphone and raspberry that serves as server as well as device monitoring tools Webcam and spotlights attached pad Board House. Smartphone server as the controller to send instructions to the Raspberry through the application website, the IP Address 192.168.1.2, which is next to the device to be monitored, according to customer wishes.

\section{2). Using Internet Network}

In the picture above is the development of the local connection, so that consumers can monitor electrical devices (webcams and floodlights), through an internet connection. In Figure 3.3 above shows the Modem Router that functions as a media liaison local and internet connection. Users can connect to the Internet by accessing http://www.penelitianmonitoringgedung.ngrok.com on the smartphone.

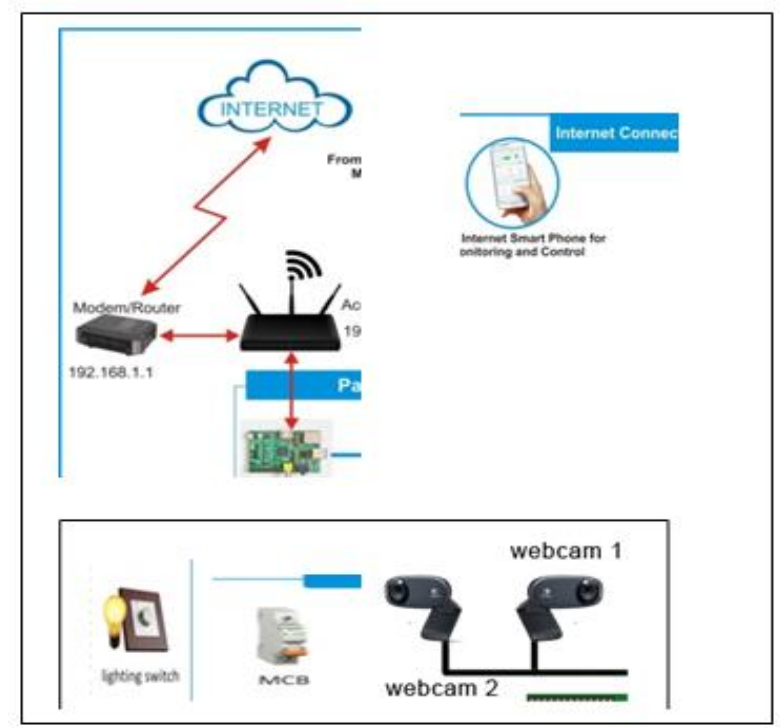

Figure 3.3 Arsitektur Jaringan Internet 


\subsection{Results}

\section{Results And Discussion}

Design Applications are made by the research team can be seen in Picture 3.2 and Picture 3.3. Software that has been refined subsequently downloaded to a device that is ready functionalized raspberry. The results obtained after trials conducted on the monitor can be seen in Table 1 and 2 below.

Table 1. Testing For Short-circuit Protection System (MCB)

\begin{tabular}{|l|l|l|}
\hline \multirow{3}{*}{ MCB } & Status Smartphone & Keterangan \\
\cline { 2 - 3 } & ON & Semua Perangkat Listrik Berfungsi, dengan tegangan 220V \\
\cline { 2 - 3 } & OFF & Semua Perangkat Listrik tidak Berfungsi, dengan tegangan 0V \\
\hline
\end{tabular}

Table 2. Testing For Webcam Monitor Tool

\begin{tabular}{|l|l|l|}
\hline \multirow{3}{*}{ Webcam } & Status Smartphone & Keterangan \\
\cline { 2 - 3 } & ON & Semua Perangkat Webcam Berfungsi \\
\cline { 2 - 3 } & OFF & Semua Perangkat Webcam Tidak Berfungsi \\
\hline
\end{tabular}

Table 3. Testing For The lights Highlight

\begin{tabular}{|l|l|l|}
\hline \multirow{3}{*}{ Lampu Sorot } & Status Smartphone & Keterangan \\
\cline { 2 - 3 } & ON & Semua Lampu Sorot Menyala, dengan Tegangan 220V \\
\cline { 2 - 3 } & OFF & Semua Lampu Sorot Padam, dengan Tegangan 0 V \\
\hline
\end{tabular}

\subsection{Discussion}

Testing Equipment Monitoring System for the Webcam and floodlights have been functioning well, this is illustrated in Table 1, which time MCB- ON, then all electrical devices, which is currently on the Board House functions, including floodlights, and webcams, wherein the device can be controlled by means of manual and automatically can be controlled from a distance or close by using a Smartphone.

In Table 2. Shows that at the time of the Smartphone in ON (enabled)condition, all the webcams can monitor the situation around him, according to the distance range. Conversely when the Smartphone in the OFF condition, automatically the Webcam function is OFF. Circumstances ON - OFF can be controlled from near and far distances by using a Smartphone. The same thing applies to tabel.3, which enabled to control the floodlights mounted on Board House.

\subsection{Conclusion}

\section{Conclusions And Recommendations}

1. Software raspberry-based monitoring system has been functioning well, it is proved by the functioning monitoring system for all attached peripheral devices, such as some webcams, some spotlights and the MCB safety devices that are on the school environment, using a Smartphone.

2. Prototype raspberry-based Monitoring Tool has been created for controlling the device webcams, floodlights and security $\mathrm{MCB}$ are functioning properly, so that it can monitor and secure school environment (through Board House) from the danger of short-circuit, both from distance, or close, using a Smartphone.

3. Interface and Application raspberry-based monitoring system that has been created to monitor the entire school environment, has been functioning well and can monitor and secure all devices (MCB, webcams and electric lights) contained in the school environment.

\subsection{Recommendation}

1. Monitoring Tool (webcams) have been made for monitoring, in order to add on some particular point, given the vastness of the respective school environment.

2. monitoring tool needs to be placed in the room- Classroom and Laboratory whose function is to monitor all activities of students during the school day

\section{References}

[1]. Alim .2012. Pengertian PHP dan MYSQL [online] (http://e-komputer.blogspot.Com /2012/10/ pengertian-php-mysql.html), diakses tanggal 06 Februari 2015

[2]. Budi Raharjo. 2011. Belajar Pemrograman Web. Bandung : Modula.

[3]. Christopher D.Celestial, and Arc E.P. Mercolesia. 2013. Smart Home Electricity Management System Using Cloud Computing (SHEMS). Journal of Advance in Computer Networks, Vol.1. No.1. March 2013.

[4]. Drajat, Iwan Setiawan. 2011. Aplikasi Smart Card sebagai Pengunci Elektronis pada Smart Home. Universitas Diponegoro Semarang.

[5]. Eisa Al Eisa, Imam Bakh .2012. Intelligent Home Monitoring Using RSSI in Wireless Sensor Networks. International Journal of Computer Networks and Communications (IJCNC) Vol.4. No.6. November 2012.

[6]. Firman Adi Laksono. 2012. Pengertian IP Address,(http://bozsetia.blogspot.com/2012/03/ pengertian.ip.address. lengkap.html), diakses tanggal 06 Februari 2015 
[7]. Hayder Hasin (2007), Object Oriented Programming with PHP5. Birmingham: Packt Publishing Ltd.

[8]. Matt Richardson and Shwn Wallace (2013). Getting Started with Rapsberry Pi. Amerika Serikat : O’Reilly Media, Inc., 1005 Gravenstein Highway North, Sebastopol, CA 95472

[9]. Muhammad Hasan Akbar S.Pd, Jas. 2013. Pengertian Access Point Dan Fungsinya. (http://www.kampusinfo.com/2013/04/pengertian-access-point dan- fungsinya.html), diakses tanggal 06 Februari 2015

[10]. McLaughlinn Brett (2012), PHP \& MySQL: The Missing Manual. California: O’ Reilly Media, Inc.

[11]. Nevel Oktaviandy. 2012. Metode Penelitian eksperimen, (http://nevelmangelep. wordpress.com /2012/02/27/metode penelitianksperimen), diakses tanggal 06 Februari 2015

[12]. Schildt Herbert (2007), Java: The Complete Reference $7^{\text {th }}$ Edition. New York: The McGraw-Hills.

[13]. Zaid Amin. 2013. Metode Perancangan Jaringan dengan metode PPDIOO, (http://news. palcomtech.com/metode-perancanganjaringan-dengan-model-PPDIOO/), diakses tanggal 06 Februari 2015 